\title{
STUDI PENAMBATAN MOLEKUL SENYAWA-SENYAWA BIOAKTIF DARI KULIT AKAR MURBEI (Morus sp.) TERHADAP RESEPTOR TNF- $\alpha$
}

\author{
Muhammad Aswad $^{1}$, Lisa Christine ${ }^{2}$, Nursamsiar², Besse Hardianti ${ }^{2}$ \\ ${ }^{1}$ Fakultas Farmasi, Universitas Hasanuddin, Makassar, Indonesia \\ ${ }^{2}$ Sekolah Tinggi Ilmu Farmasi, Makassar, Indonesia
}

Kata Kunci :

Docking, Morus, TNF- $\alpha$, reseptor, interaksi

\begin{abstract}
ABSTRAK
Tumor necrosis factor alfa (TNF)- $\alpha$ memiliki peranan penting dalam patogenesis beberapa penyakit inflamasi. Murbei dilaporkan memiliki efek penghambatan pada proses inflamasi. Penelitian ini ditujukan untuk mengetahui interaksi antara senyawa-senyawa bioaktif yang terdapat pada murbei terhadap reseptor TNF- $\alpha$ dengan metode simulasi docking molekuler. Docking dilakukan dengan menggunakan program AutoDock 4.2, dengan menambatkan senyawa pada sisi aktif reseptor TNF- $\alpha$ (PDB ID : 3EWJ) secara in silico. Hasil docking menunjukkan bahwa senyawa-senyawa bioaktif dari kulit akar murbei dapat berinteraksi dengan sisi aktif. Interaksi terbaik ditunjukkan oleh senyawa 86 dengan energi bebas ikatan -13,03 12kkal/mol, yang berinteraksi dengan residu asam amino yang penting pada reseptor TNF- $\alpha$ dan memiliki ikatan hidrogen yang sama pada Leu348, Glu406 dan Gly349 dengan menggunakan pembanding (1S, 3R, 6S)-4-oxo-6\{4-[2-phenylquinolon-4-yl)methoxy]phenyl $\}$-5-azaspiro [2.4] heptane-1-carboxylic acid sebagai ligan alami.
\end{abstract}

\section{PENDAHULUAN}

Tumor Necrosis Factor alfa (TNF)- $\alpha$ merupakan sitokin multifungsi penting yang mengatur peradangan, pertahanan inang, respon imun, dan apoptosis. Fungsi biologis utama TNF adalah untuk menginduksi peradangan melalui regulasi transkripsi gen, terutama melalui jalur sinyal NFкВ dan AP-1, yang mengarah pada ekspresi sejumlah besar gen. TNF- $\alpha$ diakui sebagai mediator penting peradangan dan respon imun serta apoptosis. TNF- $\alpha$ juga memainkan peran penting dalam patogenesis beberapa penyakit inflamasi, termasuk rheumatoid arthritis dan penyakit radang usus. Fungsi penting TNF- $\alpha$ lainnya adalah induksi apoptosis, yang biasanya terjadi tanpa adanya sinyal bersamaan oleh NF-kB (1).

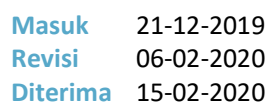

Korespondensi

Muhammad Aswad aswadfar@unhas.ac.id

Copyright

(C) 2020 Majalah Farmasi Farmakologi Fakultas

Farmasi - Makassar

Diterbitkan tanggal 16-02-2020

DOI

10.20956/mff.v23i3.9399

Dapat Diakses Daring

Pada:

http://journal.unhas.ac.id

/index.php/mff
Kulit akar murbei disebut Sang-Bai-Pi dalam bahasa Cina dan Sōhakuhi dalam bahasa Jepang pertama kali tercatat di Shennong Herbal. Kulit akar Morus digunakan dalam pengobatan tradisional Tiongkok, telah digunakan dalam dosis 9$15 \mathrm{~g}$ dalam bentuk rebusan untuk pengobatan batuk, dahak kuning, bronkhitis, xerophthalmia, nefritis, penyakit paru, luka yang diiris, dan sebagainya. Kimura, et.al melaporkan efek penghambatan Morus alba pada metabolisme arakidonat pada platelet tikus (2). Ekstrak Morus alba menunjukkan efek penghambatan pada isoenzim siklooksigenase (COX). Total flavonoid Morus alba $(400 \mathrm{mg} / \mathrm{kg})$ jelas dapat menghambat pembengkakan telinga xilena dan permeabilitas kapiler akibat peradangan oleh asam asetat. Studi melaporkan bahwa ekstrak Morus alba menekan produksi oksida nitrat (NO), prostagland dalam E2 (PGE2), ekspresi mRNA COX-2 pada RAW 264.7 sel dan menghambat aktivasi Nuclear Factor kappa B (NF-KB) (3).

Sejumlah besar senyawa anti-inflamasi ditemukan dari Morus alba. Morusin, oxydihydromorusin (morusinol), kuwanon C, mulberrofuran A, kuwanon $\mathrm{G}$ (moracenin $\mathrm{B}$ atau albanin $\mathrm{F}$ ), kuwanon $H$ (moracenin A atau albanin G), sanggenon D, dan mulberrofuran G (albanol A), J, $\mathrm{Q}$ ditemukan mempengaruhi metabolisme arakidonat pada platelet tikus. Morusin, kuwanon C, sanggenon B, C, D, E, O menghambat aktivitas COX. Oxyresveratrol menghambat peningkatan stimulasi ekspresi nitrat oksida yang diinduksi oleh lipopolisakarida (LPS). Mornigrol D dan norartocarpetin menunjukkan penghambatan pelepasan $\beta$-glukuronidase. Moracin C, D, O, P, R, artoindonesianin $\mathrm{O}$, alabafuran $\mathrm{A}$, mulberrofuran $\mathrm{J}$, L, Y, kuwanon A, C, E, T, sanggenon F, sanggenol L dan morusin menunjukkan efek penghambatan pada produksi nitrat oksida. Kuwanon J 2,4,10" trimetil eter, kuwanon $\mathrm{R}$ menghambat aktivitas NF- $\kappa$ B. Cudraflavone B menghambat ekspresi gen dan sekresi Tumor Necrosis Factor alfa (TNF)- $\alpha$ dengan menghalangi translokasi NF- $\kappa$ B. Kuwanon E, kuwanon G dan norartocarpanon secara signifikan menghambat produksi IL-6 pada sel epitel paru (A549) dan produksi nitrat oksida pada makrofag paru-paru. Asam kafein dan asam coumaric menghambat produksi ekspresi PGE2 dan mRNA COX-2 pada RAW 264.7 sel. Moracin C, mulberrofuran $\mathrm{Y}$, mulberrofuran $\mathrm{H}$, kuwanon $\mathrm{C}, \mathrm{E}$, oxydihydromorusin, soroceal, dan sanggenon $\mathrm{E}, \mathrm{H}$ menghambat sekresi translokasi nuklir TNF- $\alpha$, IL$1 \beta$ dan NF- $\kappa$ B pada makrofag yang dipicu oleh lipopolisakarida (LPS). Moracin M ditemukan sebagai inhibitor phosphodiesterase-4 (PDE4) yang efektif (3).

Dalam upaya penelitian ini, 100 senyawa-senyawa bioaktif kulit akar Murbei sebagai penghambat aktivasi reseptor TNF- $\alpha$ dilakukan dengan menggunakan studi docking molekuler dimana interaksi antara reseptor protein dan ligan diprediksi dan dianalisis. Studi docking molekuler 
dilakukan untuk memprediksi afinitas pengikatan antara semua senyawa bioaktif kulit akar Murbei dengan TNF- $\alpha$, yang menghasilkan konformer bioaktif dari keseluruhan dataset.

\section{METODE PENELITIAN}

\section{Alat dan Bahan Penelitian}

Bahan-bahan yang digunakan dalam peneltian ini adalah struktur molekul tiga dimensi (3D) TNF- $\alpha$ (PDB ID: 3EWJ) (Zhuyan, G., et.al. 2008) yang diperoleh dari database online Protein Data Bank (www.pdb.org), dan senyawa-senyawa bioaktif kulit akar Murbei (Morus alba Linn.) yang digunakan terdapat pada Tabel 1.

Perangkat keras yang digunakan pada penelitian ini berupa prosesor Intel Core ${ }^{\mathrm{TM}} \mathrm{i}$, hard disk 500 GB SATA, Monitor ASUS A43S 14.0 inch, Random Access Memory (RAM) DDR3 2 GB dengan IC Hinyx, dan sistem operasi Windows 7 Home Basic

Perangkat lunak yang digunakan adalah Sistem operasi Windows ${ }^{\circledR}$ 7, Program yang digunakan adalah Arguslab 4.1 (www.arguslab.com) digunakan untuk mengkonversikan format file .hin dari HyperChem 8.7 ke format file .pdb, program paket AutoDock 4.2 (http://autodock.scripps.edu/) digunakan untuk mempersiapkan struktur protein, struktur ligan, file parameter grid, file parameter docking, dan menstimulasi proses docking molekuler, program paket Autogrid 4.2 (The Scripps Research Institute) digunakan untuk mempersiapkan grid, program paket ChemOffice 8.0 (http://www.cambridgesoft.com/) untuk menggambar struktur dua dimensi (2D) dan tiga dimensi (3D) ligan (senyawa-senyawa bioaktif kulit akar Murbei (Morus alba (Linn.)), Discover Studio Visualixer 4.5 digunakan untuk visualisasi, Program HyperChem 8.7 (Hypercube Inc.) digunakan untuk optimasi geometri dan analisis sifat ligan (senyawa-senyawa bioaktif kulit akar Murbei.

Cara Kerja

Preparasi Reseptor TNF- $\alpha$

Struktur tiga dimensi (3D) TNF- $\alpha$ (PDB ID: 3EWJ) sebagai reseptor ditampilkan pada paket program Discover Studio Visualizer 4.5, Chain B dipisahkan dari Chain A dengan cara dipilih view, hierarchy, lalu hilangkan water, ligand groups dan Chain $A$ lalu disimpan dalam format file .pdb. Dengan menggunakan program AutoDock Tools 4.2 struktur Chain B yang telah terpisah kemudian diberi atom hidrogen polar sedangkan muatan parsial tiap atom dihitung dengan menggunakan compute gasteiger yang terdapat pada menu edit di dalam paket program Autodock Tools 4.2, lalu disimpan dalam format file .pdbq. Kemudian pilih grid, macromolecule, open, dan no lalu struktur Chain $B$ disimpan dalam file berformat .pdbqt.

\section{Preparasi Ligan}

Persiapan ligan diawali dengan membuat struktur dua dimensi (2D) dengan menggunakan program ChemDraw Ultra 8.0 dalam paket program ChemOffice 8.0, dilanjutkan dengan struktur tiga dimensi (3D) ligan yang dibuat menggunakan Chem3D 8.0 pada paket program ChemOffice 8.0 dan disimpan dalam format file .mol. Struktur tiga dimensi (3D) tersebut selanjutnya dilakukan optimasi geometri menggunakan program HyperChem 8.7. Pada optimasi geometri dilakukan perhitungan semi-empirikal dengan cara dipilih setup, semi-empirical method, AM1, compute, geometry optimization, polak-ribiere, RMS gradient $0.001 \mathrm{kcal} /(\AA \mathrm{mol})$ or 30000 maximum cycles di dalam paket program HyperChem 8.7 .
Struktur ligan yang telah dioptimasi selanjutnya dianalisis sifat molekulnya lalu disimpan dalam format file .hin, kemudian dikonversi ke dalam format file .pdb dengan menggunakan paket program ArgusLab 4.1 untuk selanjutnya digunakan pada paket program Autodock Tools 4.2. Dengan menggunakan paket program Autodock Tools 4.2 senyawa ligan diberi All hydrogen, Merge Non Polar lalu dimasukkan Kollman charges yang terdapat pada menu edit, dan file tersebut disimpan dalam format .pdbq, dilanjutkan dengan input torsion tree lalu disimpan dalam format .pdbqt.

\section{Validasi Metode Docking}

Validasi dilakukan untuk membuktikan bahwa Autodock 4.2 dapat digunakan untuk melakukan docking ligan terhadap reseptor TNF- $\alpha$. Validasi dilakukan dengan melakukan redocking ligan asli ke dalam sisi aktif reseptornya. Docking dilakukan dengan kondisi software default, tidak ada perubahan run atau grid. Besar grid box adalah $(40 \times 40 \times 40) \AA$ dengan nilai koordinat kantung ikatan disesuaikan dengan data koordinatnya.

\section{Simulasi Docking}

Kantung ikatan pada TNF- $\alpha$ sebagai reseptor tempat ligan dapat terikat, ditentukan melalui qsite finder. Grid dibentuk dengan dimensi (40x40x40) Å agar dapat melingkupi seluruh residu asam amino yang berperan dalam ikatan ligan dengan reseptor TNF- $\alpha$ dan spasi 0,375 angstrom untuk menjaga akurasi perhitungan energi. Grid dibentuk di lokasi struktur senyawa yang terikat. Kemudian informasi mengenai reseptor, ligan dan dimensi grid disimpan dalam file berformat .gpf, peta potensial elektrostatik, peta grid AutoGrid 4.2 hasil perhitungan disimpan dalam file berformat .glg. Chain $B$ TNF- $\alpha$ sebagai reseptor ligan.

Dimensi grid sebesar (40x40x40) Å dibentuk menggunakan paket program AutoGrid 4.2. Dimensi (40x40x40) A dipilih karena sudah mampu melingkupi residu-residu asam amino yang berperan dalam ikatan antara ligan dengan reseptor TNF- $\alpha$. Proses docking terpisah untuk masing-masing dimensi grid dilakukan dengan Lamarckian Algorithm pada paket program AutoDock 4.2. Hasil proses docking kemudian disimpan dalam file berformat .dlg.

\section{HASIL DAN PEMBAHASAN}

Dalam penelitian ini, digunakan struktur tiga dimensi (3D) reseptor TNF- $\alpha$ (PDB ID: 3EWJ) sebagai reseptor yang terdaftar di Protein Data Bank (PDB) memiliki data eksperimental sebagai berikut: metode difraksi X-Ray dengan resolusi $1.85 \AA$ A , dengan nama ligan asli (1S,3R,6S)-4-oxo-6\{4-[(2-phenylquinolin-4-yl)methoxy]phenyl $\quad 5$ azaspiro [2.4] heptane-1-carboxylic acid. Dengan menggunakan program Autodock Tools 4.2 dilakukan penentuan grid box pada daerah yang diketahui sebagai sisi aktif dari protein. Penentuan grid box ini meliputi pengaturan letak parameter box dan penentuan besarnya grid box menggunakan spacing (angstrom). Pada (Gambar 1.) protein 3EWJ ini diperoleh hasil pengaturan grid box sebagai berikut: center_ $x=48.607$, center $y=30.91$ dan center $_{-} z=43.381$ dengan penentuan spacing (angstrom) sebesar $0.375 \AA$.

Ligan yang digunakan adalah senyawa-senyawa bioaktif kulit akar Murbei (Morus alba Linn.). Struktur masing-masing ligan disketsa menggunakan software ChemOffice 8.0 dan dioptimasi geometri menggunakan software HyperChem 8.7 dengan metode. Optimasi geometri struktur senyawa uji merupakan langkah pertama yang harus dilakukan pada preparasi ligan atau senyawa uji. Masing-masing senyawa uji dilakukan optimasi geometri agar diperoleh konformasi molekul yang stabil dan memiliki energi potensial rendah (4). 
Validasi proses docking dilakukan menggunakan Autodock 4.2. Validasi dilakukan terhadap sisi aktif dari ligan asli, yaitu (1S,3R,6S)-4-oxo-6-\{4-[(2-phenylquinolin-4-yl)methoxy] phenyl\}5azaspiro[2.4] heptane-1-carboxylic acid pada hasil kristalografi. Validasi dilakukan pada kondisi tanpa molekul air, keberadaan air mencerminkan kondisi fisiologis tubuh. Secara teoritis, air akan menghalangi ikatan ligan dengan reseptornya karena air dapat membentuk ikatan hidrogen dengan reseptor (5).

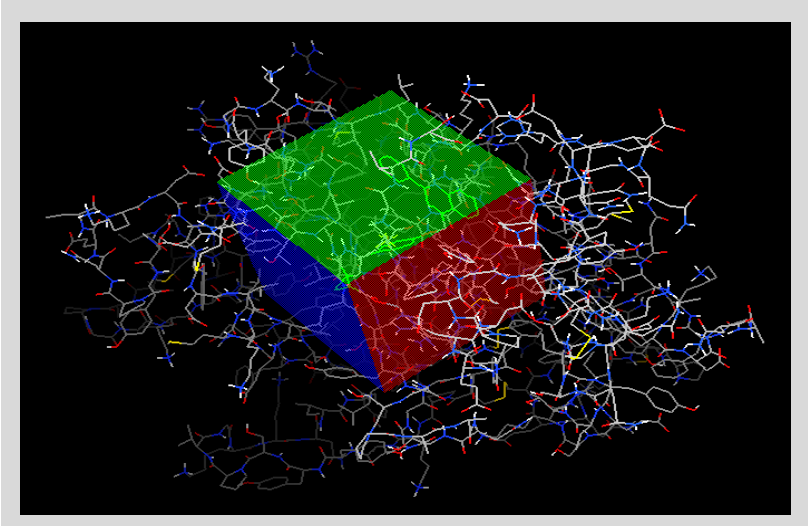

Gambar 1. Preparasi protein menggunakan Autodock Tools 4.2

Pada proses validasi ini akan dibandingkan antara posisi ligan asli terhadap reseptor yang telah diuji secara eksperimental dengan posisi ligan yang sama (ligan copy) bila ligan copy tersebut di-docking-kan yakni pada koordinat $\mathrm{X}=48,607 \AA, \mathrm{Y}=30,91 \AA \mathrm{Z}=43,381 \AA$. Dasar yang digunakan untuk memberikan penilaian adalah nilai Root Mean Square Deviation (RMSD). Metode yang digunakan dikatakan valid jika nilai RMSD yang diperoleh $<2 \AA$ A. Besarnya nilai $R o o t$ Mean Square Deviation (RMSD) menunjukkan keakuratan perhitungan dimana jika nilai RMSD $<2 \AA$ A ini menunjukkan bahwa semakin kecil kesalahan dari hasil perhitungan sehingga dikatakan lebih akurat perhitungannya, sedangkan jika nilai RMSD > 2 Å ini menunjukkan bahwa penyimpangan dari hasil perhitungan lebih besar (6).

Hasil redocking menunjukkan nilai Root Mean Square Deviation (RMSD) sebesar $0,87 \AA$, yang menunjukkan bahwa posisi atom-atom pada ligan dari hasil redocking (ligan copy) tidak berbeda terlalu jauh dengan posisi pada ligan hasil kristalografi (ligan asli) (Gambar 2). Hasil tersebut menunjukkan bahwa reseptor 3EWJ dapat digunakan untuk proses docking (7).

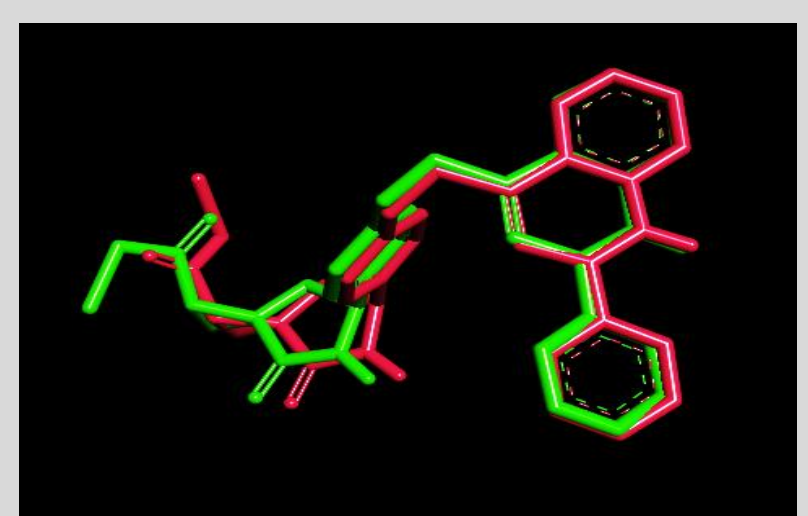

Gambar 2. Overlay posisi ligan asli dan ligan copy (Merah muda = ligan asli; Hijau tua = ligan copy)

Docking molekuler dilakukan terhadap seluruh ligan atau senyawa uji yang telah dioptimasi menggunakan Autodock 4.2 pada sisi aktif yang sama dengan yang digunakan pada proses redocking ligan asli. Docking molekuler pada ligan uji dilakukan dengan cara yang sama dengan proses validasi menggunakan ukuran dan posisi grid box yang sama. Semua docking dilakukan dengan menghilangkan molekul air karena keberadaan air akan menghalangi ikatan ligan dengan reseptornya (4).

Parameter yang diamati untuk penentuan afinitas ligan terhadap reseptor adalah energi bebas ikatan $(\Delta G)$ dan residu asam amino. Afinitas ligan terhadap reseptor ditentukan oleh nilai $\Delta$ G. Semakin negatif nilai $\Delta \mathrm{G}$ menunjukkan afinitas ligan yang semakin tinggi. Ligan uji dengan residu asam amino dan ikatan hidrogen yang mendekati ligan alami menunjukkan kemiripan jenis interaksi dalam hal ini menggambarkan kemiripan aktivitas (8).

Penelitian ini dilakukan pengulangan atau running sebanyak 10 kali dalam sekali docking, sehingga diperoleh 10 pose ligan dengan energi bebas ikatan yang berbeda-beda. Proses running yang berulang memberikan pengaruh pada nilai energi bebas ikatan. Dalam penelitian ini dipilih hasil docking pada peringkat 1 sampai 5 yang memiliki energi bebas ikatan yang paling rendah dan dibandingkan dengan asam amino yang ada pada senyawa uji dan ligan alami.

Berdasarkan hasil docking menunjukkan bahwa hampir semua senyawa uji dapat berinteraksi dengan reseptor TNF$\alpha$. Interaksi tersebut dapat dilihat dari nilai energi ikatan bebas yang nilainya rendah. Beberapa di antaranya tidak dapat berinteraksi karena nilai energi bebas ikatan yang besar. Energi bebas ikatan juga sebagai parameter sebuah kestabilan proses docking. Semakin negatif nilai energi bebas ikatan menunjukkan tingkat kestabilan yang baik antara ligan dan protein target sehingga ikatan yang terbentuk akan semakin kuat.

Pada (Tabel 1) terlihat bahwa senyawa yang memiliki energi ikatan paling rendah, yakni senyawa 86 dengan energi ikatan paling rendah, yaitu $-13,03 \mathrm{kkal} / \mathrm{mol}$. Senyawa ini juga memiliki asam amino yang mirip dengan key residue atau rantai samping ligan asli, yaitu Leu348, Glu406, dan Gly349 dengan ikatan hidrogen yang mirip ligan asli (Gambar 3). Hasil yang diperoleh juga menunjukkan adanya ikatan hidrogen yang mempengaruhi kestabilan interaksi. Perpaduan antara ikatan-ikatan yang berinteraksi lemah seperti Van der Waals, dipo-dipol dan elektrostatik pada gugus non polar ligan dan gugus non polar protein target membentuk interaksi hidrofobik yang mampu menstabilkan interaksi ligan dan protein target dengan menurunkan nilai energi bebas ikatan. Pada (Tabel 1 dan Tabel 2), tabel hasil docking dan residu asam amino, tidak terlihat ada senyawa $21,22,28,37,38,39,42,53,60,84,90$ dan 94. Hal itu menunjukkan bahwa senyawa-senyawa tersebut bernilai positif, sehingga tidak dapat berinteraksi dengan sisi aktif protein target.

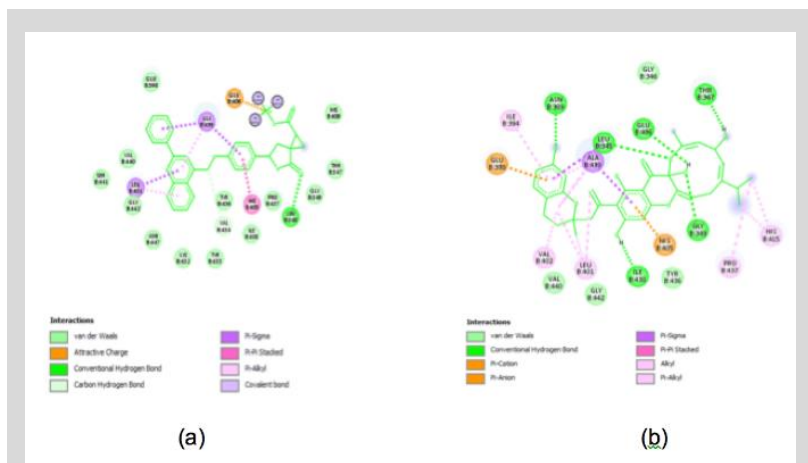

Gambar 3. Tampilan 2D interaksi ligan alami (a) dan senyawa 86 dengan target 
Tabel 1. Hasil docking.

\begin{tabular}{|c|c|c|c|}
\hline No. & Senyawa & $\begin{array}{l}\text { Energi Bebas lkatan } \\
\text { (kkal/mol) }\end{array}$ & Ikatan Hidrogen \\
\hline 1. & Ligan Alami & -15.11 & $\begin{array}{l}\text { Leu348, Leu395, Glu398, His405, Leu401, His405, Val434, Met435, Tyr433, } \\
\text { Tyr436, Tyr433, Ser441, Asp443, Ser441, Asn447, His444, Lys432 }\end{array}$ \\
\hline 2. & Senyawa 1 & -7.87 & Thr347, Asp344, His405, Leu401, His405, Val434, Glu406, Met345 \\
\hline 3. & Senyawa 2 & -11.51 & $\begin{array}{l}\text { Leu348, Gly349, Leu395, Glu398, Val402, Glu398, His405, Val434, Tyr436, } \\
\text { Tyr433, Asp443, Ser441, Asp443, His444, Asn447, Lys432, Glu406, Gly349, } \\
\text { Tyr433 }\end{array}$ \\
\hline 4. & Senyawa 3 & -10.02 & $\begin{array}{l}\text { Leu348, Val402, Glu398, His405, Leu401, His405, Val434, Tyr436, Tyr433, } \\
\text { Ala439, Met345, Ile438, Glu406 }\end{array}$ \\
\hline 5. & Senyawa 4 & -9.05 & His405, Leu401, His405, Val434, Tyr436, Pro437 \\
\hline 6. & Senyawa 5 & -9.06 & $\begin{array}{l}\text { Leu348, Gly349, His405, Leu401, His405, Val434, Glu406, Val402, Tyr436, } \\
\text { Tyr433, Val440, Val434, Gly349 }\end{array}$ \\
\hline 7. & Senyawa 6 & -9.63 & His405, Leu401, His405, Val434, Tyr436, Tyr433, Ala439, Pro437, Glu406 \\
\hline 8. & Senyawa 7 & -10.54 & $\begin{array}{l}\text { Leu348, Leu401, Lys397, Val402, Glu398, His405, Leu401, His405, Val434, } \\
\text { Met449, Tyr436, Tyr433, Asn447, Lys432, Glu398 }\end{array}$ \\
\hline 9. & Senyawa 8 & -10.57 & $\begin{array}{l}\text { Ser386, Leu348, His405, Leu401, His405, Val434, Glu406, Val402,Tyr436, } \\
\text { Tyr433, Asn447, Lys432 }\end{array}$ \\
\hline 10. & Senyawa 9 & -10.66 & $\begin{array}{l}\text { His405, Leu401, His405, Val434, Tyr436, Tyr433, Asn447, Lys432, Tyr433, } \\
\text { Glu406, Pro437 }\end{array}$ \\
\hline 11. & Senyawa 10 & -10.23 & $\begin{array}{l}\text { Val402, Glu398, His405, Leu401, His405, Val434, Tyr436, Tyr433, Val4401, } \\
\text { Ser441, Asp443, His444, Lys432, Val440, Ser441, Tyr436 }\end{array}$ \\
\hline 12. & Senyawa 11 & -10.91 & $\begin{array}{l}\text { His405, Leu401, Val434, His409, His415, Tyr436, Tyr433, Asn447, Lys432, } \\
\text { Glu406, Pro437 }\end{array}$ \\
\hline 13. & Senyawa 12 & -7.68 & Thr347, Asp344, His405, Leu401, His405, Val434, Ala439, Tyr436 \\
\hline 14. & Senyawa 13 & -5.93 & Val402, Glu398, Leu401, His405, Tyr436, Tyr433, Glu406 \\
\hline 15. & Senyawa 14 & -6.50 & Leu348, Gly349, His405, Leu401, His405, Val434, Tyr436 \\
\hline 16. & Senyawa 15 & -10.65 & Leu348, Gly349, Val402, Glu398, His405, Val434, Tyr436, Tyr433 \\
\hline 17. & Senyawa 16 & -11.30 & $\begin{array}{l}\text { Leu348, Gly349, His405, Val434, Glu406, Val402, Tyr436, Tyr433, Asn447, } \\
\text { Lys432, Met345, Ala439 }\end{array}$ \\
\hline 18. & Senyawa 17 & -9.22 & $\begin{array}{l}\text { His405, Leu401, His405, Val434, Glu406, Val402, Tyr436, Tyr433, Asp443, } \\
\text { Ser441, His444, Asn447 }\end{array}$ \\
\hline 19. & Senyawa 18 & -8.89 & $\begin{array}{l}\text { Gly349, His405, Leu401, His405, Val434, Glu406, Val402, Val434, Met449, } \\
\text { Tyr436, Tyr433, Lys432, Asn447 }\end{array}$ \\
\hline 20. & Senyawa 19 & -8.46 & Thr347, Asp344, Ala351 \\
\hline 21. & Senyawa 20 & -9.67 & His405, Val434, Tyr436, Tyr433, Gly349, Glu406, Tyr433, Pro437, Gly346 \\
\hline 22. & Senyawa 23 & -8.44 & $\begin{array}{l}\text { Leu348, His405, Val434, His415, Asp443, Ser441, His444, Asn447, Lys432, } \\
\text { Pro437, Glu406, Gly346 }\end{array}$ \\
\hline 23. & Senyawa 24 & -9.53 & His405, Leu401, His405, Val434, His415, Gly349, Leu401, lle438, Pro437, Gly346 \\
\hline 24. & Senyawa 25 & -4.44 & $\begin{array}{l}\text { Leu348, Gly349, Leu395, Glu398, Leu401, Lys397, Val402, Glu398, Val402, } \\
\text { Thr403, Ala399, Thr403, Ala399, His405, Leu401, His405, Val434, Tyr436, } \\
\text { Tyr433, Asp443, Ser441 }\end{array}$ \\
\hline 25. & Senyawa 26 & -7.44 & Tyr390, Pro437 \\
\hline 26. & Senyawa 27 & -5.30 & Leu348, Gly349, His405, Leu401, His405, Val434, Tyr436, Tyr433 \\
\hline 27. & Senyawa 29 & -9.69 & $\begin{array}{l}\text { Thr347, Asp344, Thr347, Leu395, Glu398, Val402, His405, Leu401, Val434, } \\
\text { Glu406, His415, Pro437 }\end{array}$ \\
\hline 28. & Senyawa 30 & -10.55 & Val402, Glu398, His405, Leu401, Val434, Tyr436, Tyr433, Asn447, Lys432 \\
\hline 29. & Senyawa 31 & -7.56 & Leu348, Ala439 \\
\hline 30. & Senyawa 32 & -7.40 & Leu3481, His405, Val434, Ala439, Gly349 \\
\hline 31. & Senyawa 33 & -5.67 & Val402, Glu398, His405, Leu401, His405, Val434, Tyr436, Tyr433 \\
\hline 32. & Senyawa 34 & -9.01 & Val402, Glu398, His405, Leu401, Val434, Tyr436, Tyr433 \\
\hline 33. & Senyawa 35 & -8.56 & $\begin{array}{l}\text { Thr347, Asp344, Val402, Glu398, His405, Leu401, Val434, Glu406, Leu401, } \\
\text { Tyr436, Met345 }\end{array}$ \\
\hline 34. & Senyawa 36 & -9.98 & $\begin{array}{l}\text { Leu348, His405, Leu401, His405, Val434, Glu406, Val402, Tyr436, Tyr433, } \\
\text { Asp443, Ser441, His444, Asn447, Lys432 }\end{array}$ \\
\hline 35. & Senyawa 39 & -7.18 & $\begin{array}{l}\text { Ser386, Leu348, Leu395, Glu398, Val402, Glu398, His405, Leu401, Val434, } \\
\text { Tyr436, Ala439 }\end{array}$ \\
\hline 36. & Senyawa 40 & -7.06 & $\begin{array}{l}\text { Ser386, Leu348, Asn389, Leu395, Glu398, Val402, Glu398, His405, Val434, } \\
\text { Tyr436, Tyr433, Gly346, Met345 }\end{array}$ \\
\hline
\end{tabular}




\begin{tabular}{|c|c|c|c|}
\hline No. & Senyawa & $\begin{array}{l}\text { Energi Bebas lkatan } \\
\quad \text { (kkal/mol) }\end{array}$ & Ikatan Hidrogen \\
\hline 37. & Senyawa 41 & -7.37 & Leu395, Glu398, Ala4391, Met345, Ala439, Pro437, Gly349 \\
\hline 38. & Senyawa 43 & -9.85 & $\begin{array}{l}\text { Leu348, Gly349, Val402, Glu398, His405, Val434,Tyr436, Tyr433, His444, } \\
\text { Asn447, Lys432, Gly346 }\end{array}$ \\
\hline 39. & Senyawa 44 & -11.09 & $\begin{array}{l}\text { Thr347, Asp344, Leu395, Glu398, Val402, His405, Leu401, His405, Val434, } \\
\text { Glu406, Gly442, Pro437, Met345 }\end{array}$ \\
\hline 40. & Senyawa 45 & -10.36 & His405, Leu401, Val434, Tyr436, Tyr433, Leu401, Thr347, Met345 \\
\hline 41. & Senyawa 46 & -9.42 & $\begin{array}{l}\text { Thr347, Asp344, Leu348, Gly349, Val402, Glu398 } \\
\text { Glu406, Val402, Tyr436, Tyr433, Pro437 }\end{array}$ \\
\hline 42. & Senyawa 47 & -8.34 & $\begin{array}{l}\text { Gly349, Val402, Glu398, His405, Leu401, His405, Val434, Glu406, Tyr436, } \\
\text { Tyr433, Tyr4361, Asn447, Lys432 }\end{array}$ \\
\hline 43. & Senyawa 48 & -11.12 & His405, Val434, Glu406, Val402, Tyr436, Tyr433 \\
\hline 44. & Senyawa 49 & -8.16 & Thr347, Asp344, His405, Leu401, His405, Val434, Leu401, Tyr436, Met345 \\
\hline 45. & Senyawa 50 & -9.92 & $\begin{array}{l}\text { Leu348, Gly349, Leu395, Glu398, Val402, His405, Leu401, Val434, Tyr436, } \\
\text { Tyr433, Ile438 }\end{array}$ \\
\hline 46. & Senyawa 51 & -8.88 & Gly349, His405, Val434, Glu406, Val402, Tyr436, Tyr433, Asn447, Lys432, \\
\hline 47. & Senyawa 52 & -7.61 & Leu348, Gly349, Glu406, Val402, Ala439 \\
\hline 48. & Senyawa 54 & -9.91 & $\begin{array}{l}\text { His405, Leu401, Val434, Glu406, Val402, Tyr436, Tyr433, Asp443, Ser441, } \\
\text { His444, Asn447, Lys432, Val440 }\end{array}$ \\
\hline 49. & Senyawa 55 & -10.46 & His405, Leu401, Val434, Tyr436, Tyr433, Asn447, Lys432, Glu406 \\
\hline 50. & Senyawa 56 & -9.92 & His405, Leu401, Val434, Tyr436, Tyr433, Gly346 \\
\hline 51. & Senyawa 57 & -9.01 & Leu348, Gly349, His405, Leu401, His405, Val434, Tyr436, Tyr433, Pro437 \\
\hline 52. & Senyawa 58 & -10.92 & $\begin{array}{l}\text { Leu348, Gly349, His405, Leu401, His405, Val434, His415, Tyr436, Tyr433, } \\
\text { Val440, Asp443, Ser441, His444, Asn447, Lys432, lle438 }\end{array}$ \\
\hline 53. & Senyawa 59 & -10.61 & $\begin{array}{l}\text { Val402, Glu398, His405, Leu401, Val434, Met449, Tyr436, Tyr433, Asp443, } \\
\text { Ser441, Asn447, Lys432, Val440, Glu406 }\end{array}$ \\
\hline 54. & Senyawa 61 & -10.61 & $\begin{array}{l}\text { Leu348, Gly349, His405, Val434, Val434, Met449, Tyr436, Tyr433, Val440, } \\
\text { Asp443, Ser441, Asn447, Lys432, Gly349, Glu406, Val440 }\end{array}$ \\
\hline 55. & Senyawa 62 & -11.20 & $\begin{array}{l}\text { Gly349, Leu395, Glu398, Val402, His405, Leu401, Val434, Tyr436, Tyr433, } \\
\text { Val440, Asn447, Lys432, Glu406 }\end{array}$ \\
\hline 56. & Senyawa 63 & -9.16 & $\begin{array}{l}\text { Leu348, Gly349, His405, Leu401, Val434, Glu406, Val402, Tyr436, Tyr433, } \\
\text { Ala439, Gly346, Val434 }\end{array}$ \\
\hline 57. & Senyawa 64 & -10.00 & $\begin{array}{l}\text { His405, Leu401, Val434, Glu406, Val402, Tyr436, Tyr433, Asp443, Ser441, } \\
\text { Asp443, His444, Asn447, Lys432, }\end{array}$ \\
\hline 58. & Senyawa 65 & -9.36 & His405, Leu401, Val434, Tyr436, Thr347 \\
\hline 59. & Senyawa 66 & -8.76 & $\begin{array}{l}\text { His405, Val434, His409, His415, His444, Asn447, Lys432, Glu406, Pro437, } \\
\text { Gly354 }\end{array}$ \\
\hline 60. & Senyawa 67 & -12.56 & $\begin{array}{l}\text { Leu348, Gly349, His405, Leu401, His405, Val434, Met449, Tyr436, Tyr433, } \\
\text { Ala4391, Met34, Asn447 }\end{array}$ \\
\hline 61. & Senyawa 68 & -11.77 & $\begin{array}{l}\text { Thr347, Asp344, Leu348, Gly349, His405, Leu401, Val434, Met449, Tyr436, } \\
\text { Tyr433, Ala439, Asn447, Lys432, Met345 }\end{array}$ \\
\hline 62. & Senyawa 69 & -10.76 & His405, Val434, Tyr436, Tyr433, Asn447, Lys432, Glu406, Pro437 \\
\hline 63. & Senyawa 70 & -7.87 & $\begin{array}{l}\text { Leu348, Leu395, Glu398, Val402, His405, Leu401, Val434, Glu406, Ala439, } \\
\text { Tyr436 }\end{array}$ \\
\hline 64. & Senyawa 72 & -9.29 & $\begin{array}{l}\text { Leu348, His405, Leu401, Val434, Glu406, Val402, Tyr436, Tyr433, Val440, } \\
\text { Asp443, Ser441, His444, Asn447, Lys432, Ile438, Pro437, Gly346 }\end{array}$ \\
\hline 65. & Senyawa 73 & -10.43 & $\begin{array}{l}\text { Thr347, Asp344, His405, Val434, Tyr436, Tyr433, Asn447, Lys432, Pro437, } \\
\text { Glu406 }\end{array}$ \\
\hline 66. & Senyawa 74 & -7.28 & $\begin{array}{l}\text { Leu350, Gly349, Leu348, Glu406, Val402, His405, Leu401, Val434, Tyr436, } \\
\text { Ala439, Ile438, Pro437, His415, His409 }\end{array}$ \\
\hline 67. & Senyawa 75 & -8.94 & His405, Leu401, Met449, Tyr436, Tyr433, Asn447, Lys432, Glu406, Pro437 \\
\hline 68. & Senyawa 76 & -8.36 & $\begin{array}{l}\text { His405, Leu401, Val434, Tyr436, Tyr433, Asn447, Lys432, Val434, Glu406, } \\
\text { Pro437 }\end{array}$ \\
\hline 69. & Senyawa 77 & -9.38 & $\begin{array}{l}\text { Val402, Glu398, His405, Leu401, Val434, Glu406, Val402, His409, His415, } \\
\text { Thr347 }\end{array}$ \\
\hline 70. & Senyawa 78 & -8.53 & $\begin{array}{l}\text { Leu348, Gly349, His405, Leu401, Val434, Glu406, Val402, Tyr436, Tyr433, } \\
\text { Ile438, Asn447 }\end{array}$ \\
\hline 71. & Senyawa 79 & -10.97 & $\begin{array}{l}\text { Leu348, Thr347, Gly349, His409, Leu350, His415, Glu406, Tyr436, His405, } \\
\text { Ile438, Asn447, Leu401, Val434, Val402, Ala439 }\end{array}$ \\
\hline 72. & Senyawa 80 & -9.31 & $\begin{array}{l}\text { Gly349, Val402, Glu398, His405, Leu401, Val434, Glu406, Val402, Tyr436, } \\
\text { Tyr433, His444, Asn447, Lys432 }\end{array}$ \\
\hline 73. & Senyawa 81 & -5.29 & Leu348, Gly349, His405, Leu401, Val434, Glu406 \\
\hline
\end{tabular}


Tabel 1. Hasil docking (lanjutan)

\begin{tabular}{|c|c|c|c|}
\hline No. & Senyawa & $\begin{array}{l}\text { Energi Bebas lkatan } \\
\text { (kkal/mol) }\end{array}$ & Ikatan Hidrogen \\
\hline 74. & Senyawa 82 & -11.40 & $\begin{array}{l}\text { His405, Leu401, His405, Val434, Glu406, Val402, Tyr436, Tyr433, His444, } \\
\text { Asn447, Lys432, Met345, Ala439 }\end{array}$ \\
\hline 75. & Senyawa 83 & -10.56 & $\begin{array}{l}\text { Gly349, His405, Leu401, Val434, Tyr436, Tyr433, Ala439, Asn447, Lys432, } \\
\text { Glu406 }\end{array}$ \\
\hline 76. & Senyawa 85 & -7.56 & Ala351, Glu406, Gly346 \\
\hline 77. & Senyawa 86 & -13.03 & $\begin{array}{l}\text { Leu348, Gly349, Asn389, Leu395, Glu398, Val402, His405, Leu401, His405, } \\
\text { Val434, Ile438, Glu406, Thr347 }\end{array}$ \\
\hline 78. & Senyawa 87 & -5.35 & $\begin{array}{l}\text { Leu395, Glu398, Leu401, Lys397, Val402, His405, Val434, Tyr436, Tyr433, } \\
\text { Asp443, Ser441, His444, Asn447, Lys432, Glu406 }\end{array}$ \\
\hline 79. & Senyawa 88 & -6.10 & $\begin{array}{l}\text { Leu395, Glu398, Val402, Glu398, His405, Leu401, His405, Val434, Val440, } \\
\text { Asp443, Ser441, His444, Asn447, Tyr436, Glu398, Ser441 }\end{array}$ \\
\hline 80. & Senyawa 89 & -9.72 & Leu348, Gly349, His405, Val434, Tyr436, Tyr433, His444, Asn447, Lys432 \\
\hline 81. & Senyawa 91 & -8.63 & $\begin{array}{l}\text { Gly349, Val402, Glu398, His405, Leu401, His405, Val434, Glu406, Tyr436, } \\
\text { Tyr433, Asn447, Lys432 }\end{array}$ \\
\hline 82. & Senyawa 92 & -9.35 & $\begin{array}{l}\text { Val402, Glu398, His405, Leu401, Val434, Glu406, Val402, Tyr436, Tyr433, } \\
\text { Thr347 }\end{array}$ \\
\hline 83. & Senyawa 93 & $-11,64$ & $\begin{array}{l}\text { Leu348, Gly349, His405, Leu401, Val434, Glu406, Val402, His444, Asn447, } \\
\text { Lys432 }\end{array}$ \\
\hline 84. & Senyawa 95 & -8.50 & Leu348, Gly349, Glu406, Ala439, Met345, Pro437 \\
\hline 85. & Senyawa 96 & -8.68 & Gly349, His405, Leu401, His405, Val434, Gly346, Glu406 \\
\hline 86. & Senyawa 97 & -8.58 & $\begin{array}{l}\text { His409, His415, Leu350, Ala351, Met345, Thr347, Pro437, Ile438, Tyr433, } \\
\text { Tyr436, Met435, Val436, Leu401, His405, Val402, Ala439, Glu406 }\end{array}$ \\
\hline 87. & Senyawa 98 & -7.68 & Asn389 \\
\hline 88. & Senyawa 99 & -8.31 & Gly349, His405, Val434, Glu406, Val402, Tyr436, Tyr433, Ile438 \\
\hline 89. & Senyawa 100 & -8.11 & Ala351, Glu406 \\
\hline
\end{tabular}

Tabel 2. Senyawa-senyawa bioaktif dalam kulit akar murbei

\begin{tabular}{|c|c|c|}
\hline No. & Nama Senyawa & Struktur Senyawa \\
\hline 1. & Sophoflavescenol & \\
\hline 2. & $\begin{array}{l}\text { 2'-(6,7-dihydroxy-3,7-dimethyl-2-octen-1-yl)-3',5',6- } \\
\text { trihydroxy-2-arylbenzofuran }\end{array}$ & \\
\hline 3. & $\begin{array}{l}\text { 2'-(6,7-dihydroxy-3,7-dimethyl-2-octen-1-yl)-3'-methoxy- } \\
\text { 5',6-dihydroxy-2-arylbenzofuran }\end{array}$ & \\
\hline 4. & $\begin{array}{l}\text { 2'-(6-hydroxy-3,7-dimethyl-2,7-octadien-1-yl)-3'- } \\
\text { methoxy-5',6-dihydroxy-2-arylbenzofuran }\end{array}$ & \\
\hline
\end{tabular}




\begin{tabular}{|c|c|c|}
\hline No. & Nama Senyawa & Struktur Senyawa \\
\hline 5. & 2,4,2',4'-tetrahydroxychalcone & \\
\hline 6. & $\begin{array}{l}\text { 2'-[[3-methyl-3-(4-methyl-3-penten-1-yl)-2- } \\
\text { oxiranyl]methyl]-3',5',6-trihydroxy-2-arylbenzofuran }\end{array}$ & \\
\hline 7. & $\begin{array}{c}2^{\prime}, 4^{\prime}, 5 \text {-trihydroxy-3-( }\left(y, \gamma, \gamma-\text {-hydroxydimethyl)propyl-2", } 2^{\prime \prime} \text { - }\right. \\
\text { dimethylpyrano }\left(5^{\prime \prime}, 6^{\prime \prime}: 6,7\right) \text {-flavone }\end{array}$ & \\
\hline 8. & 3'-geranyl-3-prenyl-2',4',5',7-tetrahydroxyflavone & \\
\hline 9. & $\begin{array}{c}\text { 4'-(6,6-dimethyl-5-hydroxyl-2- } \\
\text { methylenecyclohexylmethyl)-3',5',6-trihydroxy-2- } \\
\text { arylbenzofuran }\end{array}$ & \\
\hline 10. & $\begin{array}{c}\text { 4'-(6,7-dihydroxy-3,7-dimethyl-2-octen-1-yl)-3',5',6'- } \\
\text { trihydroxy-2-arylbenzofuran }\end{array}$ & \\
\hline 11. & $\begin{array}{l}\text { 4'-(6-hydroxy-3,7-di-methyl-2,7-octadien-1-yl)-3',5',6- } \\
\text { trihydroxy-2-arylbenzofuran }\end{array}$ & \\
\hline 12. & Kurarinol & \\
\hline 13. & 5,7-dihydroxychromone & \\
\hline 14. & 5,7-dihydroxycoumarin-7-me ether & \\
\hline 15. & 5'-geranyl-4'-methoxy-5,7,2'-trihydroxyflavone & \\
\hline 16. & 5'-geranyl-5,7,2',4'-tetrahydroxyflavone & \\
\hline 17. & $7,2^{\prime}, 4^{\prime}, 6^{\prime}$-tetrahydroxy-6-geranylflavonone & \\
\hline
\end{tabular}




\begin{tabular}{|c|c|c|}
\hline No. & Nama Senyawa & Struktur Senyawa \\
\hline 18. & 7-methoxy-5,4'-dihydroxyflavanonol & \\
\hline 19. & $\alpha$-Amyrin Acetate & \\
\hline 20. & Albafuran C & \\
\hline 21. & Albanol B & \\
\hline 22. & Australisine A & \\
\hline 23. & Australisine B & \\
\hline 24. & Australisine C & \\
\hline 25. & Australone B & \\
\hline 26. & Betulinic Acid & \\
\hline
\end{tabular}




\begin{tabular}{|c|c|c|}
\hline No. & Nama Senyawa & Struktur Senyawa \\
\hline 27. & Caffeic Acid & \\
\hline 28. & Cathayanon A & \\
\hline 29. & Chalcomoracin & \\
\hline 30. & Cudraflavone B & \\
\hline 31. & Cyclomorusin & \\
\hline 32. & Cyclomulberrin & \\
\hline 33. & Ethyl B-Resorcylate & \\
\hline 34. & Kuwanon A & \\
\hline 35. & Kuwanon C & \\
\hline 36. & Kuwanon E & \\
\hline 37. & Kuwanon G & \\
\hline
\end{tabular}


Tabel 2. Senyawa-senyawa bioaktif dalam kulit akar murbei (lanjutan)

\begin{tabular}{|c|c|c|}
\hline No. & Nama Senyawa & Struktur Senyawa \\
\hline 38. & Kuwanon $\mathrm{H}$ & \\
\hline 39. & Kuwanon J 2,4,10-Trimethyl Ether & \\
\hline 40. & Kuwanon J & \\
\hline 41. & Kuwanon L & \\
\hline 42. & Kuwanon M & \\
\hline 43. & Kuraridin & \\
\hline 44. & Kuwanon R & \\
\hline 45. & Kuwanon T & \\
\hline
\end{tabular}




\begin{tabular}{|c|c|c|}
\hline No. & Nama Senyawa & Struktur Senyawa \\
\hline 46. & Kanzonol C & \\
\hline 47. & Poinsettifolin A & \\
\hline 48. & Poinsettifolin B & \\
\hline 49. & Leachianone G & \\
\hline 50. & Licoflavone C & \\
\hline 51. & Dorsilurin A & \\
\hline 52. & Dorsilurin B & \\
\hline 53. & Moracenin D & \\
\hline
\end{tabular}




\begin{tabular}{|c|c|c|}
\hline No. & Nama Senyawa & Struktur Senyawa \\
\hline 54. & Morachalcone A & \\
\hline 55. & Moracin D & \\
\hline 56. & Moracin E & \\
\hline 57. & Moracin M & \\
\hline 58. & Moracin O & \\
\hline 59. & Moracin P & \\
\hline 60. & Moracin Q & \\
\hline 61. & Moracin R & \\
\hline 62. & Mornigrol D & \\
\hline 63. & Morusalbanol A & \\
\hline 64. & Dorsmanin A & \\
\hline 65. & Morusin & \\
\hline
\end{tabular}




\begin{tabular}{|c|c|c|}
\hline No. & Nama Senyawa & Struktur Senyawa \\
\hline 66. & Mulberrofuran C & \\
\hline 67. & Mulberrofuran F & \\
\hline 68. & Mulberrofuran $\mathrm{G}$ & \\
\hline 69. & Mulberrofuran $\mathrm{H}$ & \\
\hline 70. & Mulberrofuran J & \\
\hline 71. & Mulberrofuran $Q$ & \\
\hline 72. & Mulberroside A & \\
\hline 73. & Mulberroside C & \\
\hline 74. & Neocyclomorusin & \\
\hline 75. & Norartocarpanone & \\
\hline 76. & Norartocarpetin & \\
\hline
\end{tabular}




\begin{tabular}{|c|c|c|}
\hline No. & Nama Senyawa & Struktur Senyawa \\
\hline 77. & Oxydihydromorusin & \\
\hline 78. & Oxyresveratrol & \\
\hline 79. & Dorsmanin B & \\
\hline 80. & Dorsmanin C & \\
\hline 81. & P-Coumaric Acid & \\
\hline 82. & Sanggenol A & \\
\hline 83. & Sanggenol L & \\
\hline 84. & Sanggenol M & \\
\hline 85. & Dorsmanin D & \\
\hline 86. & Sanggenon B & \\
\hline 87. & Sanggenon D & \\
\hline
\end{tabular}




\begin{tabular}{|c|c|c|}
\hline No. & Nama Senyawa & Struktur Senyawa \\
\hline 88. & Sanggenon E & \\
\hline 89. & Sanggenon $\mathrm{F}$ & \\
\hline 90. & Sanggenon G & \\
\hline 91. & Sanggenon $\mathrm{H}$ & \\
\hline 92. & Sanggenon I & \\
\hline 93. & Sanggenon $\mathrm{N}$ & \\
\hline 94. & Sanggenon T & \\
\hline 95. & Soroceal B & \\
\hline 96. & Soroceal & \\
\hline 97. & Dorsmanin E & \\
\hline
\end{tabular}


Tabel 2. Senyawa-senyawa bioaktif dalam kulit akar murbei (lanjutan)

\begin{tabular}{|c|c|c|}
\hline No. & Nama Senyawa & Struktur Senyawa \\
\hline 98. & Dorsmanin J & \\
\hline 99. & Dorsmanin I & \\
\hline 100. & Uvaol & \\
\hline
\end{tabular}

\section{KESIMPULAN}

Dari 100 senyawa bioaktif kulit akar Murbei (Morus alba Linn.) ditemukan adanya 88 senyawa yang dapat berinteraksi dengan reseptor Tumor Necrosis Factor alfa (TNF)- $\alpha$, dan senyawa 86 (Sanggenon B) menunjukkan interaksi terbaik (residu asam amino atau rantai samping mirip ligan asli) dengan energi bebas ikatan -13,03 kkal/mol.

\section{DAFTAR PUSTAKA}

1. Levine, S.J., Tumor Necrosis Factor Alpha (TNF- $\alpha$ ), National Institutes of Health, Bethesda, MD, USA, Published by Elsevier Ltd, 2017.

2. Kimura, Y., Okuda, H., Nomura, T., Fukai, T., \& Arichi, S. Effects of phenolic constituents from the Mulberry tree on Arachidonate metabolism in Rat platelets. Journal of Natural Products, 1986; 49: 639644

3. Wei, H., Zhu, JJ., Liu, XQ., Feng, WH., Wang, ZM. and Yan, LH, Review Of Bioactive Compounds From Root Barks Of Morus Plants (Sang-Bai-Pi) And Their Pharmacological Effects, Cogent Chemistry 2016; 2:1212320
4. Lestari, Tresna, Studi Interaksi Senyawa Turunan 1,3-Dibenzoiltiourea Sebagai Ribonukleotida Reduktase Inhibitor, Jurnal Farmasi Indonesia, 2015; 7(3):163-169

5. Pebriana, B. R., Romadhon, F. A., Yunianto, A., Rokhman, R. M., Fitriyah, Q. N., Jenie, I. R., et.al. Docking Kurkumin Dan Senyawa Analognya Pada Reseptor Progesteron: Studi Interaksinya Sebagai Selective Progesterone Receptor Modulators (SPRms), Pharmacon, 2008; 9 (1):14-20

6. Ferwadi, $S$, Gunawan, $\mathrm{R}$, dan Astuti, W Studi Docking Molekular Senyawa Asam Sinamat Dan Derivatnya Sebagai Inhibitor Protein 1j4x Pada Sel Kanker Serviks, Jurnal Kimia Mulawarman, 2017; 14 (2):84-90

7. Bissantz, C. G., and Folkers, D. Rognan, Protein-based Virtual Screening of Chemical Databases : Evaluation of Different Docking/Scoring Combinations. Journal of Medicinal Chemistry, 2000; 43:4759-4767.

8. Pratama, F., R., Moh. 2016, Studi Docking Molekular Senyawa Turunan Kuinolin Terhadap Reseptor Estrogen- $\alpha$, Jurnal Surya Medika, 2 (1):1-7.

9. Pranowo, H. D. Kimia Komputasi, Pusat Kimia Komputasi Indonesia Austria, Jurusan Kimia FMIPA, Universitas Gadjah Mada, Yogyakarta; 2006

10. Paul, J. Gane., and Philip, M. Dean., Recent Advances In Structure-Based Rational Drug Design, Current Opinion in Structural Biology, 2000; $10: 401-404$ 